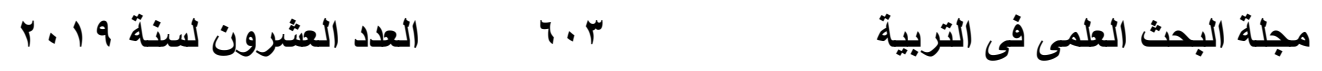

A Proposed Vision For The Establishment Of An Education Institution For Kuwait In The Light Of The International Initiative Education For All

Researcher / Hamad Al-Ajmi

Specialized Trainer in the General

Authority

For applied education and training

Kuwait 


\section{Abstract :}

The study aimed at reaching a proposed vision for the establishment of an education institution for Kuwait in the light of the International Initiative for Education for All. The study sample consisted of (97) educational experts in Kuwait. The results of the study reached the following : Policy and objectives : Provide citizens and residents of Kuwait with the opportunity to pursue their education, Contribute to the building of the good Kuwaiti man, Contribute to the preparation of the person who possesses the principles of knowledge.

Programs : Administration science, Environment Science, Kindergarten, Law, Information Systems, Tourism and Hotels.

Methods : Virtual Library, Virtual coefficient, Virtual Classrooms, E-Book, E-mail, Online discussion forums, Simultaneous and asynchronous courses, Training in business institutions.

Management and Finance :

Management : Establishment of sub-centers of the institution in the governorates of Kuwait and appointing each director, Kuwait Education Corporation is subject to the Ministry of Education, The Board of Trustees of the Ministry of Education is managed by Kuwait Education Corporation, The Board of Trustees of the Ministry shall choose the organizational structure of Kuwait Education Corporation, The Board of Trustees of the Ministry shall appoint the President of Kuwait Education Corporation, The President of the Foundation selects Education for Kuwait as Vice President of Kuwait Education Foundation, The head of the institution chooses the vice president of the institution to manage student affairs, Kuwait Foundation granted autonomy to academic institutions, The institution enjoys autonomy in administrative aspects, The Board of Trustees shall regulate the internal laws of Kuwait Education Corporation.

Key Words : Proposed Vision - Education For All - Education Kuwait. 


\title{
A Proposed Vision For The Establishment Of An Education Institution For Kuwait In The Light Of The International Initiative Education For All
}

\author{
Researcher / Hamad Al-Ajmi \\ Specialized Trainer in the General Authority \\ For applied education and training \\ Kuwait
}

\section{[1] Introduction :}

Education for All has succeeded in developing a diverse range of countries changing the conditions and environments in education around the world including new countries and education experience through the coordination of donor activity groups and EFA. (Tikly, 2016 : 58) Education for all as a global system that is flexible in the face of great tensions and contradictions, but more dependent on the ability of government and non-governmental actors to recognize, deal with and overcome imbalances in educational authority to pave the way for the success of EFA in those countries. (Tikly, 2016:58).

The results showed the positive impact of TFA teachers and their students' grades, and surpassed the teachers who received teaching in specialized theoretical and practical schools. $(X u, 2011: 450)$ As the TFA summer schools offer them a unique individual education. (Cooper, et al., 1996 : 266), As well as the positive impact of these teachers in their personal desire to join the profession of education and what makes him struggling to join the teaching profession, in addition to his desire for charity and humanitarian work. $(\mathrm{Xu}, 2011: 451)$

In Kuwait, the results of a study prepared by a British advisory body Entitled "Vision of Kuwait by 2030"- That Kuwaiti education is in danger due to several factors, including the low level of achievement of Kuwaiti students. (Tony Blair, 2009: 51) Weak knowledge development and management in the State of Kuwait and what adds many challenges and constraints (Al-Azmi 2014), (Harbi, 2006), (Khurshid, 2014), In addition to the low rating and Kuwait's decline in education at the center (651) globally, and 19th place in the Arab world (TopUnversities, QS., (2018), This is not commensurate with the huge number of strategic visions and objectives set by the educational institutions in the State of Kuwait, which indicates that there is a lack of management and development of education. 


\section{[2] Research Questions :}

The study aims to answer the following questions :

1- What is the vision of education experts in establishing an education for all institution in the State of Kuwait ?

2- What is the proposed vision for establishing an education institution for Kuwait?

\section{[3] Materials and Methods :}

\section{[3.1] Participants :}

The following table shows the distribution of the participants in the study according to their degrees.

\section{Table (1)}

Distribution of sample members by scientific grade

\begin{tabular}{|c|c|c|}
\hline Degree & Frequency & $\%$ \\
\hline Ph.D & 91 & $93.8 \%$ \\
\hline M.A. & 3 & $3.1 \%$ \\
\hline BA & 3 & $3.1 \%$ \\
\hline Total & 97 & $100 \%$ \\
\hline
\end{tabular}

It is clear from the previous table that most of the respondents have a Ph.D degree, reaching 93.8\%.

Table (2)

Distribution of the sample according to the current job

\begin{tabular}{|c|c|c|}
\hline Job & Frequency & $\%$ \\
\hline Professor & 20 & $20.6 \%$ \\
\hline Co-professor & 56 & $56.7 \%$ \\
\hline Associate Professor & 3 & $3.1 \%$ \\
\hline Administrative & 19 & $19.6 \%$ \\
\hline Total & 97 & $100 \%$ \\
\hline
\end{tabular}

The table shows that the largest proportion of the sample members are from the category of Co-professor and reached 56.7\%.

Table (3)

Distribution of sample members by specialization

\begin{tabular}{|c|c|c|}
\hline specialization & Frequency & $\%$ \\
\hline educational & 18 & $18.6 \%$ \\
\hline Not educational & 79 & $81.4 \%$ \\
\hline Total & 97 & $100 \%$ \\
\hline
\end{tabular}


It is clear from the previous table that most of the sample of noneducational respondents reached $79 \%$.

\section{Table (4)}

Distribution of sample members according to experience variables

\begin{tabular}{|c|c|c|}
\hline experience & Frequency & $\%$ \\
\hline Less than 10 years & 36 & $37.1 \%$ \\
\hline More than 10 years & 61 & $62.9 \%$ \\
\hline Total & 97 & $100 \%$ \\
\hline
\end{tabular}

It is clear from the above table that most of the respondents with more than 10 years of experience have reached $62.9 \%$.

\section{[4] Results :}

\section{[4.1] Policy and objectives :}

The following table shows the extent to which experts from the study sample agree on the policy and objectives that a Kuwait education institution may adopt.

\section{Table (5)}

Respondents' response to policy And the objectives that a Kuwaiti

\begin{tabular}{|c|l|c|c|c|c|c|c|c|c|}
\hline \multirow{2}{*}{ Objectives } & \multicolumn{2}{|c|}{ Agree } & \multicolumn{2}{|c|}{ Neutral } & \multicolumn{2}{|c|}{ disagree } & \multirow{2}{*}{$\mathbf{X}^{\mathbf{2}}$} & $\begin{array}{c}\text { priori } \\
\text { ty } \\
\text { level }\end{array}$ \\
\cline { 2 - 8 } 1 & $\mathbf{F}$ & $\mathbf{\%}$ & $\mathbf{F}$ & $\mathbf{\%}$ & $\mathbf{F}$ & $\mathbf{\%}$ & \\
\hline $\begin{array}{l}\text { Achieving } \\
\text { democratic } \\
\text { education and } \\
\text { equal } \\
\text { opportunities for } \\
\text { education. }\end{array}$ & 85 & 87.6 & 12 & 12.4 & 0 & 0 & $54.93^{*}$ & 5 \\
\hline 2 & $\begin{array}{l}\text { Contribute to the } \\
\text { building of the } \\
\text { good Kuwaiti } \\
\text { man. } 94\end{array}$ & 96.6 & 3 & 3.1 & 0 & 0 & $85.37^{*}$ & 2 \\
\hline 3 & $\begin{array}{l}\text { Provide citizens } \\
\text { and residents of } \\
\text { Kuwait with the } \\
\text { opportunity to } \\
\text { pursue their }\end{array}$ & 100 & 0 & 0 & 0 & 0 & $64.48^{*}$ & 1 \\
\hline
\end{tabular}




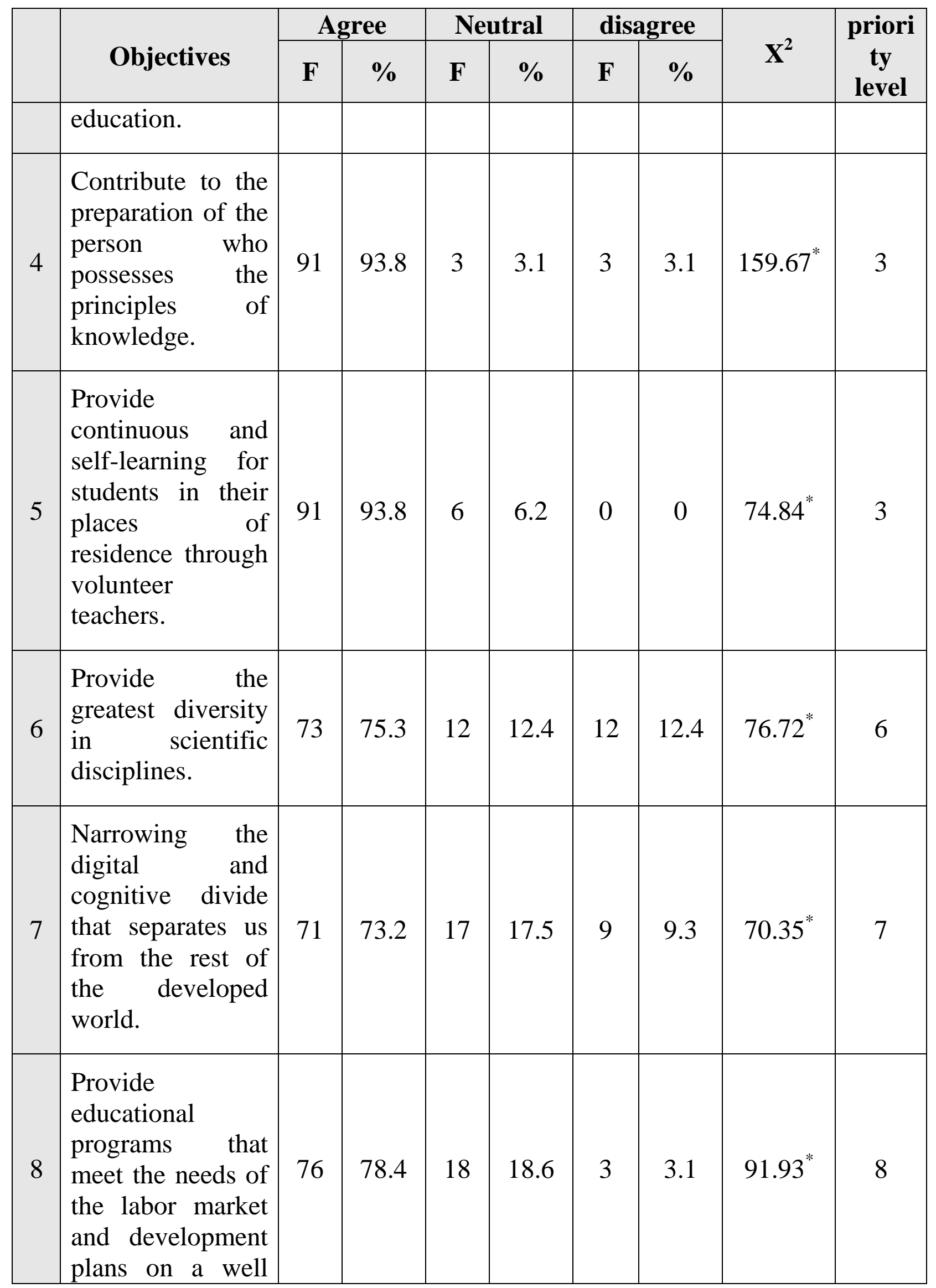




\begin{tabular}{|c|c|c|c|c|c|c|c|c|c|}
\hline & \multirow{2}{*}{ Objectives } & \multicolumn{2}{|c|}{ Agree } & \multicolumn{2}{|c|}{ Neutral } & \multicolumn{2}{|c|}{ disagree } & \multirow{2}{*}{$\mathbf{X}^{2}$} & \multirow{2}{*}{$\begin{array}{c}\text { priori } \\
\text { ty } \\
\text { level }\end{array}$} \\
\hline & & $\mathbf{F}$ & $\%$ & $\mathbf{F}$ & $\%$ & $\mathbf{F}$ & $\%$ & & \\
\hline & thought out basis. & & & & & & & & \\
\hline 9 & $\begin{array}{l}\text { Provide } \\
\text { educational } \\
\text { opportunities for } \\
\text { different social } \\
\text { groups (people } \\
\text { with special } \\
\text { needs, the poor, } \\
\text { women, the } \\
\text { elderly....) }\end{array}$ & 88 & 90.7 & 6 & 6.2 & 3 & 3.1 & $143.89^{*}$ & 4 \\
\hline 10 & $\begin{array}{l}\text { Contribute to the } \\
\text { development of } \\
\text { scientific } \\
\text { research. }\end{array}$ & 68 & 70.1 & 23 & 23.7 & 6 & 6.2 & $63.48^{*}$ & 9 \\
\hline 11 & $\begin{array}{l}\text { Relieve the } \\
\text { pressure of the } \\
\text { Ministry of } \\
\text { Education in light } \\
\text { of the continuous } \\
\text { numerical } \\
\text { increase } \\
\text { students. }\end{array}$ & 69 & 71.1 & 13 & 13.4 & 15 & 15.5 & $62.43^{*}$ & 8 \\
\hline 12 & $\begin{array}{l}\text { Education is a } \\
\text { prevailing } \\
\text { societal culture. }\end{array}$ & 88 & 90.7 & 9 & 9.3 & 0 & 0 & $64.34^{*}$ & 4 \\
\hline
\end{tabular}

(*) 0.01

Degree of Importance: The grade "1" refers to the maximum value of importance .

For the phrase (3), which ranked (1) in importance, There were statistically significant differences between the responses of the sample at (0.01) For respondents who agreed to the third objective The opportunity for citizens and residents of Kuwait to continue their education" By $(100 \%)$, This is due to the belief of the respondents in the importance of 
education and its availability to all without distinction between a citizen and a resident who did not have positive returns on the homeland.

For the phrase (2), which ranked (2) in importance, There were statistically significant differences between the responses of the sample at (0.01) For respondents who agreed to the second objective "Contributing to building the good Kuwaiti man" By (96.6\%), This is the confidence of respondents in science to build a strong knowledge.

\section{[4.2] Programs and methods :}

\section{[4.2.1] Programs :}

The following table shows the extent to which the study sample agrees with the programs that a Kuwaiti education institution may provide.

Table (6)

Response of sample members with respect to With programs that may be provided by an education institution for Kuwait

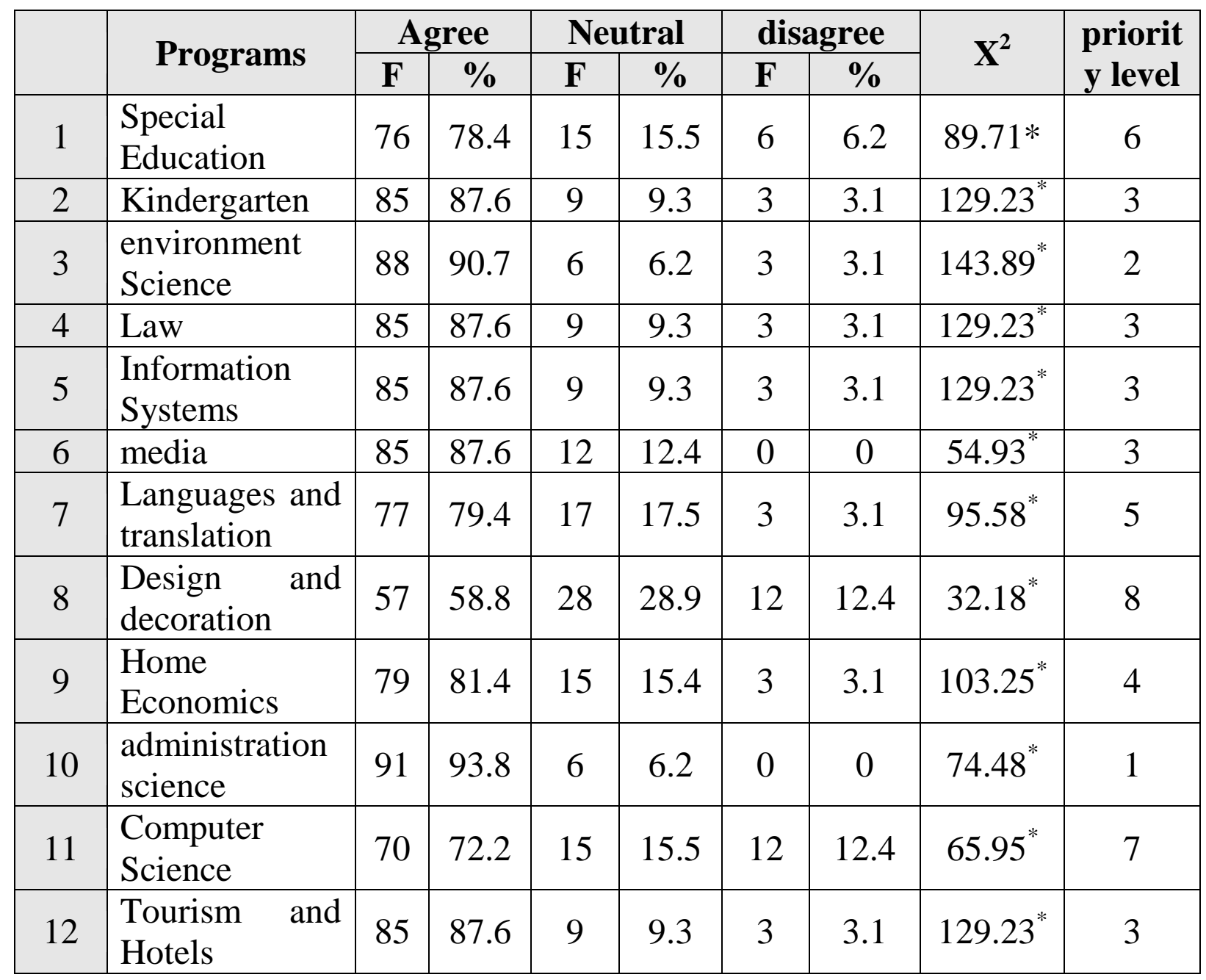

(*) 0.01 
Degree of Importance: The grade "1" refers to the maximum value of importance .

For the term (10), which ranked (1) in importance, There were statistically significant differences between the responses of the sample at (0.01) In favor of the sample members who answered the approval of the administrative sciences as one of the programs that can be provided by Education for All (93.8\%), This is due to the importance of the administration in the development and success of educational institutions that suffer from many problems and challenges, the most important of which is weak management and leadership in these institutions and their ability to overcome these problems.

For the term (3), which ranked (2) in importance, There were statistically significant differences between the responses of the sample at (0.01) (90.7\%) in favor of respondents who have approved environmental science as one of the programs that can be provided by Kuwait Education Corporation This is due to the importance of this specialization due to the spread of industrial cities and environmental pollution in the State of Kuwait and the suffering of citizens of these industries and their impact on human beings, marine organisms, nature and the Kuwaiti environment in general.

\section{[4.2.2] Methods :}

The following table shows the extent to which experts from the study sample agreed on the methods that could be used in the educational process of a Kuwait education institution.

\section{Table (7)}

Response of sample members with respect to methods May be used in the educational process of an educational institution of Kuwait

\begin{tabular}{|c|c|c|c|c|c|c|c|c|c|}
\hline & \multirow{2}{*}{ Method } & \multicolumn{2}{|c|}{ Agree } & \multicolumn{2}{|c|}{ Neutral } & \multicolumn{2}{|c|}{ disagree } & \multirow{2}{*}{$\mathbf{X}^{2}$} & \multirow{2}{*}{$\begin{array}{c}\text { priori } \\
\text { ty } \\
\text { level }\end{array}$} \\
\hline & & $\mathbf{F}$ & $\%$ & $\mathbf{F}$ & $\%$ & $\mathbf{F}$ & $\%$ & & \\
\hline 1 & $\begin{array}{l}\text { Radio and television } \\
\text { broadcasting }\end{array}$ & 67 & $\begin{array}{c}69 . \\
1\end{array}$ & 27 & $\begin{array}{c}27 . \\
8\end{array}$ & 3 & 3.1 & 64.66 & 5 \\
\hline 2 & Virtual Library & 97 & $\begin{array}{c}10 \\
0\end{array}$ & 0 & 0 & 0 & 0 & - & 1 \\
\hline 3 & Virtual coefficient & 97 & $\begin{array}{c}10 \\
0\end{array}$ & 0 & 0 & 0 & 0 & - & 1 \\
\hline 4 & Virtual Classrooms & 97 & $\begin{array}{c}10 \\
0\end{array}$ & 0 & 0 & 0 & 0 & - & 1 \\
\hline 5 & E-Book & 97 & 10 & 0 & 0 & 0 & 0 & - & 1 \\
\hline
\end{tabular}




\begin{tabular}{|c|c|c|c|c|c|c|c|c|c|}
\hline & \multirow[b]{2}{*}{ Method } & \multicolumn{2}{|c|}{ Agree } & \multicolumn{2}{|c|}{ Neutral } & \multicolumn{2}{|c|}{ disagree } & \multirow{2}{*}{$\mathrm{X}^{2}$} & \multirow{2}{*}{$\begin{array}{c}\text { priori } \\
\text { ty } \\
\text { level }\end{array}$} \\
\hline & & $\mathbf{F}$ & $\%$ & $\mathbf{F}$ & $\%$ & $\mathbf{F}$ & $\%$ & & \\
\hline & & & 0 & & & & & & \\
\hline 6 & E-mail & 97 & $\begin{array}{c}10 \\
0\end{array}$ & 0 & 0 & 0 & 0 & - & 1 \\
\hline 7 & CDs and DVDs & 60 & $\begin{array}{c}61 . \\
9\end{array}$ & 28 & $\begin{array}{c}28 . \\
8\end{array}$ & 12 & 12.4 & 38.12 & 6 \\
\hline 8 & $\begin{array}{l}\text { Online discussion } \\
\text { forums }\end{array}$ & 94 & $\begin{array}{c}96 . \\
9\end{array}$ & 3 & 3.1 & 0 & 0 & 85.37 & 2 \\
\hline 9 & $\begin{array}{l}\text { Seminars and } \\
\text { seminars }\end{array}$ & 88 & $\begin{array}{c}90 . \\
7\end{array}$ & 9 & 9.3 & 0 & 0 & 64.34 & 4 \\
\hline 10 & $\begin{array}{l}\text { Simultaneous and } \\
\text { asynchronous courses }\end{array}$ & 91 & $\begin{array}{c}93 . \\
8\end{array}$ & 6 & 6.2 & 0 & 0 & 74.48 & 3 \\
\hline 11 & $\begin{array}{l}\text { Training in business } \\
\text { institutions }\end{array}$ & 91 & $\begin{array}{r}93 . \\
8\end{array}$ & 6 & 6.2 & 0 & 0 & 74.48 & 3 \\
\hline
\end{tabular}

(*) 0.01

Degree of Importance: The grade "1" refers to the maximum value of importance .

In terms of terms (2), (3), (4), (5) and (6), which ranked (1) in importance, there are statistically significant differences between the responses of the sample members at the level of (0.01) (100\%), due to the importance of these methods in delivering and delivering live or recorded live lectures, which proved their ability To create the desired impact and interaction in the success of the educational process.

\section{[4.3] Management and Finance :}

\section{[4.3.1] Management :}

Table (8)

Response of sample members with respect to the proposed administrative elements of Kuwait Education Corporation

\begin{tabular}{|c|c|c|c|c|c|c|c|c|c|}
\hline & \multirow{2}{*}{ Management } & \multicolumn{2}{|c|}{ Agree } & \multicolumn{2}{|c|}{ Neutral } & \multicolumn{2}{|c|}{$\begin{array}{l}\text { disagre } \\
\mathrm{e}\end{array}$} & \multirow[t]{2}{*}{$X^{2}$} & \multirow{2}{*}{$\begin{array}{c}\text { prior } \\
\text { ity } \\
\text { level }\end{array}$} \\
\hline & & $\mathbf{F}$ & $\%$ & $\mathbf{F}$ & $\%$ & $\mathbf{F}$ & $\%$ & & \\
\hline 1 & $\begin{array}{l}\text { Kuwait } \\
\text { Corporation is subject to } \\
\text { the Ministry of Education. }\end{array}$ & 94 & 96.9 & 3 & 3.1 & 0 & 0 & 85.37 & 1 \\
\hline 2 & $\begin{array}{l}\text { The Board of Trustees of } \\
\text { the Ministry of Education }\end{array}$ & 94 & 96.9 & 3 & 3.1 & 0 & 0 & 85.37 & 1 \\
\hline
\end{tabular}




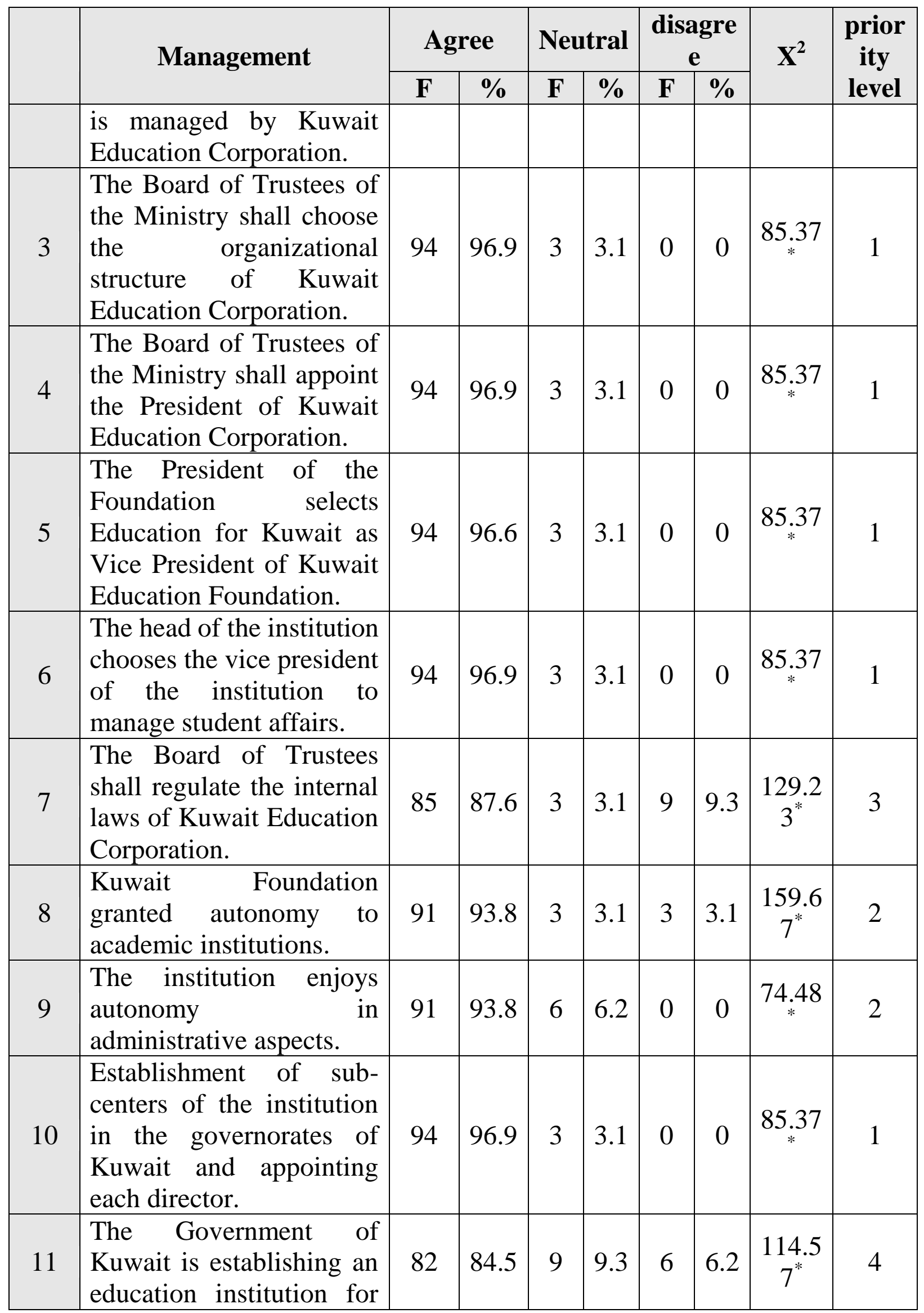




\begin{tabular}{|c|c|c|c|c|c|c|c|c|c|}
\hline & \multirow{2}{*}{ Management } & \multicolumn{2}{|c|}{ Agree } & \multicolumn{2}{|c|}{ Neutral } & \multicolumn{2}{|c|}{$\begin{array}{c}\text { disagre } \\
\mathrm{e}\end{array}$} & \multirow{2}{*}{$X^{2}$} & \multirow{2}{*}{$\begin{array}{c}\text { prior } \\
\text { ity } \\
\text { level }\end{array}$} \\
\hline & & $\mathbf{F}$ & $\%$ & $\mathbf{F}$ & $\%$ & $\mathbf{F}$ & $\%$ & & \\
\hline & Kuwait. & & & & & & & & \\
\hline 12 & $\begin{array}{l}\text { A number of charitable } \\
\text { and non-governmental } \\
\text { organizations are } \\
\text { cooperating to establish } \\
\text { education for Kuwait. }\end{array}$ & 82 & 84.5 & 9 & 9.3 & 6 & 6.2 & $\begin{array}{c}114.5 \\
7^{*}\end{array}$ & 4 \\
\hline
\end{tabular}

(*) 0.01

Degree of Importance: The grade "1" refers to the maximum value of importance .

For the terms 1, 2, 3, 4, 5, 6, and 10, which ranked 1 in importance, there are statistically significant differences between the responses of the sample members at the level of significance The Board of Trustees of the Ministry of Education selects the organizational structure of Kuwait Education Foundation. The Board of Trustees of the Ministry of Education determines the head of Kuwait Education Foundation. Kuwait Vice President of Education Foundation of Kuwait, the President of the Foundation selects the Vice President of the Foundation for the Department of Student Affairs, Establishment Foundation project in the governorates of Kuwait and appoints each director.

\section{[4.3.2] Finance :}

The following table shows the extent to which the experts from the study sample agreed on the sources of funding that can be established by Kuwait Education Corporation.

Table (9)

Respondents' response to the funding sources on which

Kuwait Education Corporation may be based

\begin{tabular}{|c|c|c|c|c|c|c|c|c|c|}
\hline & \multirow[b]{2}{*}{ Finance } & \multicolumn{2}{|c|}{ Agree } & \multicolumn{2}{|c|}{ Neutral } & \multicolumn{2}{|c|}{ disagree } & \multirow[b]{2}{*}{$\mathbf{X}^{2}$} & \multirow{2}{*}{$\begin{array}{c}\text { prior } \\
\text { ity } \\
\text { level }\end{array}$} \\
\hline & & $\mathbf{F}$ & $\%$ & $\mathbf{F}$ & $\%$ & $\mathbf{F}$ & $\%$ & & \\
\hline 1 & Government support. & 82 & 84.5 & 12 & 12.4 & 3 & 3.1 & 115.69 & 4 \\
\hline 2 & study fees. & 88 & 90.7 & 9 & 9.3 & 0 & 0 & $64.34^{*}$ & 3 \\
\hline 3 & $\begin{array}{l}\text { Revenues of the } \\
\text { various activities of } \\
\text { the institution. }\end{array}$ & 94 & 96.9 & 3 & 3.1 & 0 & 0 & $85.37^{*}$ & 2 \\
\hline
\end{tabular}




\begin{tabular}{|c|c|c|c|c|c|c|c|c|c|}
\hline & & & ree & & ral & dis & gree & & prior \\
\hline & Finance & $\mathbf{F}$ & $\%$ & $\mathbf{F}$ & $\%$ & $\mathbf{F}$ & $\%$ & $\mathrm{X}^{2}$ & $\begin{array}{c}\text { ity } \\
\text { level }\end{array}$ \\
\hline 4 & $\begin{array}{l}\text { Donations and } \\
\text { donations from local } \\
\text { authorities. }\end{array}$ & 94 & 96.9 & 3 & 3.1 & 0 & 0 & $85.37^{*}$ & 2 \\
\hline 5 & $\begin{array}{l}\text { Grants and subsidies } \\
\text { provided through } \\
\text { international } \\
\text { organizations. }\end{array}$ & 88 & 90.7 & 3 & 3.1 & 6 & 6.2 & 143.89 & 3 \\
\hline 6 & $\begin{array}{l}\text { Unconditional grants } \\
\text { from production and } \\
\text { service institutions } \\
\text { in Kuwaiti society. }\end{array}$ & 94 & 96.9 & 3 & 3.1 & 0 & 0 & $85.37^{*}$ & 2 \\
\hline 7 & $\begin{array}{l}\text { Any other resources } \\
\text { approved by the } \\
\text { Board of Trustees. }\end{array}$ & 97 & 100 & 0 & 0 & 0 & 0 & - & 1 \\
\hline
\end{tabular}

(*) 0.01

Degree of Importance: The grade "1" refers to the maximum value of importance .

For the expression (7), which ranked (1) in importance, there are statistically significant differences between the responses of the sample members at the level of (0.01) for the respondents who agreed to approve any other resources approved by the Board of Trustees as one of the sources of funding (100\%). This is due to the fact that the Board of Trustees is the legislative body of the Ministry. Its functions include monitoring the funds necessary for the establishment and development of the institution. In terms of terms (3), (4) and (6) In significance, there were statistically significant differences between the responses of the sample members at the level of significance (0.01) for the benefit of individuals (96.9\%), who have approved the income of the activities of EFA for various donations, donations from local authorities and unconditional grants from production institutions and services in Kuwaiti society as important sources of funding on which Kuwait Education Corporation can be based. The opening of the Kuwait Education Foundation to the private sector in the form of research, studies, consultancy and grants, which leads to interaction and participation in solving the problems of society, and invests the available resources of the institution in the form of financial return, where most of the institutions of Education for All developed relied on this Style very much in support of a large part of its activities and 
research in the use of different funding sources in order to achieve education for all its objectives efficiently and effectively.

\section{[4.4] International and regional cooperation :}

The following table shows the extent to which the experts from the study sample agreed on the aspects of international and regional cooperation that could be adopted by Kuwait Education Corporation.

Table (10)

The extent to which the experts from the study sample agree on the aspects of international and regional cooperation that may be adopted by Kuwait Education Corporation

\begin{tabular}{|c|c|c|c|c|c|c|c|c|c|}
\hline & \multirow{2}{*}{$\begin{array}{c}\text { International and } \\
\text { regional } \\
\text { cooperation }\end{array}$} & \multicolumn{2}{|c|}{ Agree } & \multicolumn{2}{|c|}{ Neutral } & \multicolumn{2}{|c|}{ disagree } & \multirow[b]{2}{*}{$\mathbf{X}^{2}$} & \multirow{2}{*}{$\begin{array}{c}\text { priori } \\
\text { ty } \\
\text { level }\end{array}$} \\
\hline & & $\mathbf{F}$ & $\%$ & $\mathbf{F}$ & $\%$ & $\mathbf{F}$ & $\%$ & & \\
\hline 1 & $\begin{array}{l}\text { Cooperating with } \\
\text { global education for } \\
\text { all institutions } \\
\text { known on the basis } \\
\text { of official } \\
\text { recognition and good } \\
\text { reputation. }\end{array}$ & 97 & 100 & 0 & 0 & 0 & 0 & - & 1 \\
\hline 2 & $\begin{array}{l}\text { Cooperating with } \\
\text { educational } \\
\text { institutions in } \\
\text { Kuwait to benefit } \\
\text { from their expertise } \\
\text { and support. }\end{array}$ & 88 & 90.7 & 9 & 9.3 & 0 & 0 & 64.34 & 3 \\
\hline 3 & $\begin{array}{l}\text { Cooperation with } \\
\text { educational } \\
\text { institutions for all in } \\
\text { the Arab world to } \\
\text { benefit from their } \\
\text { experiences and } \\
\text { similarities with the } \\
\text { Kuwaiti } \\
\text { environment. }\end{array}$ & 94 & 96.9 & 3 & 3.1 & 0 & 0 & 85.37 & 2 \\
\hline 4 & $\begin{array}{l}\text { Building diversified } \\
\text { partnerships with } \\
\text { major industrial and } \\
\text { commercial }\end{array}$ & 94 & 96.9 & 3 & 3.1 & 0 & 0 & 85.37 & 2 \\
\hline
\end{tabular}




\begin{tabular}{|c|c|c|c|c|c|c|c|c|}
\hline \multirow{2}{*}{$\begin{array}{c}\text { International and } \\
\text { regional } \\
\text { cooperation } \\
\end{array}$} & \multicolumn{2}{|c|}{ Agree } & \multicolumn{2}{|c|}{ Neutral } & \multicolumn{2}{|c|}{ disagree } & \multirow[b]{2}{*}{$\mathbf{X}^{2}$} & \multirow{2}{*}{$\begin{array}{c}\text { priori } \\
\text { ty } \\
\text { level }\end{array}$} \\
\hline & $\mathbf{F}$ & $\%$ & $\mathbf{F}$ & $\%$ & $\mathbf{F}$ & $\%$ & & \\
\hline $\begin{array}{l}\text { establishments in } \\
\text { Kuwait. }\end{array}$ & & & & & & & & \\
\hline
\end{tabular}

(*) 0.01

Degree of Importance: The grade "1" refers to the maximum value of importance .

In terms of the term (1), which ranked (1) in importance, there are statistically significant differences between the responses of the sample members at the level of (0.01) for the sample respondents who agreed to cooperate with the global institutions of education for all based on the official recognition and reputation as one of the aspects (100\%), which can increase the quality of study programs and help specialists in supporting Kuwait Education Foundation. This experience may also be an opportunity to help Kuwait's education to internationalize with advanced institutions in education For everyone And for the world.

In terms of expressions (3) and (4), which ranked (2) in importance, there are statistically significant differences between the responses of the sample members at the level of significance $(0.01)$ for respondents who agreed to cooperate with Arab and international organizations interested in EFA, (96.9\%) to benefit from its expertise in the field of technology, such as the development of a comprehensive student information system and the establishment of an integrated and specialized unit for the production of educational materials, design and creation Special location on the island Trent and others, industrial, commercial and major institutions play a major role in the development of human resources.

\section{[5] Conclusions :}

With regard to policy and objectives, the sample of the study on equality sought to receive knowledge between the citizen and the resident, and to contribute to the preparation of Kuwaiti citizens through the use of knowledge.

With regard to the programs used, the sample of the study preferred to concentrate on the programs of administrative sciences and environmental sciences because Kuwait enjoys a high percentage of environmental pollution, and kindergartens programs for the care of young children and the cultivation of science and knowledge from the beginning.

In terms of the methods used to teach the Kuwait Education Foundation from the point of view of experts was the general trend towards 
virtual methods based on the Internet in learning due to the spread of technology assistance from electronic devices and the Internet and the experience of citizens and residents in the use of the Internet and what may help facilitate the mission of Kuwait Education Foundation.

Experts prefer to rely on the Ministry of Education to sponsor Kuwait Education Foundation in the financial, administrative and management to work in a legitimate way to achieve its objectives.

It is preferable to rely on financial resources from private donations, donations and tuition fees, Experts also prefer to cooperate with international institutions of education for all to benefit from their expertise in achieving educational goals.

\section{[5] Result :}

In light of the aim of the study to develop a proposed vision for the establishment of an education institution for Kuwait in light of the International Initiative for Education for All, which is the following :

\section{[5.1] Policy and objectives :}

- Provide citizens and residents of Kuwait with the opportunity to pursue their education.

- Contribute to the building of the good Kuwaiti man.

- Contribute to the preparation of the person who possesses the principles of knowledge.

\section{[5.2] Programs and methods :}

\section{[5.2.1] Programs :}

- Administration science.

- Environment Science.

- Kindergarten.

- Law.

- Information Systems.

- Tourism and Hotels.

\section{[5.2.2] Methods :}

- Virtual Library

- Virtual coefficient

- Virtual Classrooms

- E-Book

- E-mail

- Online discussion forums. 
- Simultaneous and asynchronous courses.

- Training in business institutions.

\section{[5.3] Management and Finance :}

\section{[5.3.1] Management :}

- Establishment of sub-centers of the institution in the governorates of Kuwait and appointing each director.

- Kuwait Education Corporation is subject to the Ministry of Education.

- The Board of Trustees of the Ministry of Education is managed by Kuwait Education Corporation.

- The Board of Trustees of the Ministry shall choose the organizational structure of Kuwait Education Corporation.

- The Board of Trustees of the Ministry shall appoint the President of Kuwait Education Corporation.

- The President of the Foundation selects Education for Kuwait as Vice President of Kuwait Education Foundation.

- The head of the institution chooses the vice president of the institution to manage student affairs.

- Kuwait Foundation granted autonomy to academic institutions.

- The institution enjoys autonomy in administrative aspects.

- The Board of Trustees shall regulate the internal laws of Kuwait Education Corporation.

\section{[5.3.2] Finance :}

- Any other resources approved by the Board of Trustees.

- Unconditional grants from production and service institutions in Kuwaiti society.

- Donations and donations from local authorities.

- Revenues of the various activities of the institution.

- Study fees.

\section{[5.4] International and regional cooperation :}

- Cooperating with global education for all institutions known on the basis of official recognition and good reputation.

- Cooperation with educational institutions for all in the Arab world to benefit from their experiences and similarities with the Kuwaiti environment

- Building diversified partnerships with major industrial and commercial establishments in Kuwait.

- Cooperating with educational institutions in Kuwait to benefit from thseir expertise and support. 


\section{REFERENCES :}

1- Al-Azmi, Faisal Madhat Ghalab (2014). "Educational decision-making process in the State of Kuwait from 2000 to 2007. Analytical study of some decisions, Ph.D., Institute of Research and Educational Studies, Cairo University, Cairo.

2- Al-Harbi, Saud Hilal (2006). Making Educational Policy in the State of Kuwait in Light of Contemporary Global Experiences ", $\mathrm{Ph} . D$., Institute of Research and Educational Studies, Cairo University, Cairo.

3- Cooper, H., Nye, B., Charlton, K., Lindsay, J., \& Greathouse, S. (1996). The Effects Of Summer Vacation On Achievement Test Scores: A Narrative And Meta-Analytic Review. Review Of Educational Research, 66, 227-268.

4- Khurshid, Nada Hassan Abbas (2014). Developing communication efficiency for educational leaders in decision-making in Kuwait, MA, Institute of Research and Educational Studies, Cairo University, Cairo.

5- Tikly, Leon., (2016). Education For All As A Global Regime Of Educational Governance: Issues And Tensions, (International Perspectives On Education And Society Journal, Vol. (29), Emerald, Https://0810borju-1103-YHttps-Www-Emeraldinsight-

Com.Mplbci.Ekb.Eg/Doi/Full/10.1108/S1479367920140000029013\#Bib16 (9/12/2018)

6- Tony Blair (2009). Kuwaiti Education in Danger, Al-Ma'arifah Journal, No. (177), December 2009, p. 51. http://www.almarifa.com

7- Topunversities, Qs., (2018). Kuwait University, <Https: // Www. Topuniversities. Com/ University-Rankings/WorldUniversity-Rankings/2018> (8/12/2018)

8- Xu, Z., Hannaway, J., Taylor, C. (2011). Making A Difference?: The Effect Of Teach For America On Student Performance In High School, Journal Of Policy Analysis And Management, 30 (3), 447-469. Washington, Dc. 